Proc. Estonian Acad. Sci. Biol. Ecol., 2002, 51, 4, 294-302

\title{
Changes in the cytochrome P450 system of Baltic flounder from coastal waters of the Tallinn area in 1994-99
}

\author{
Sergei Bogovski*, Vladimir Muzyka, Boris Sergeyev, \\ and Svetlana Karlova
}

Institute of Experimental and Clinical Medicine, Hiiu 42, 11619 Tallinn, Estonia

Received 1 February 2002, in revised form 8 May 2002

\begin{abstract}
In order to study effects of environmental contamination, a set of biomarkers were measured in livers of flounder (Platichthys flesus) from two urban sites and one nonurban reference site of the Gulf of Finland in the vicinity of Tallinn over the period 1994-99. The total cytochrome P450 (CYP) level and the activities of aryl hydrocarbon hydroxylase (AHH), 5-aminolevulinic acid synthetase (ALA-S), and heme synthetase (HEM-S) were quantified by means of spectrophotometry. For the flounder collected from the nonurban site, significant decreases of the AHH activity and the total CYP level were observed from 1994 to $1999(p<0.05)$. The activity of ALA-S decreased slightly and the activity of HEM-S increased over the study period. In one urban site, the activities of AHH and ALA-S, as well as the total level of CYP in flounder liver, were significantly higher in 1994 compared with 1999. HEM-S activities did not show any significant changes over this time period. In the other urban site AHH activities of flounder decreased slightly between 1996 and 1999, while the total CYP level diminished drastically over these years. The activities of HEM-S increased significantly during the period investigated, while the activities of ALA-S remained unchanged. These findings suggest that contamination of the marine environments by polycyclic aromatic hydrocarbons diminished everywhere in the Tallinn area during the study period. However, the results show that the area is still contaminated, as indicated by the elevated activity of heme synthesis enzymes and the total CYP content. Therefore, the monitoring of contaminants and their effects should be continued in this region.
\end{abstract}

Key words: marine pollution, flounder, cytochrome P450, aryl hydrocarbon hydroxylase, 5-aminolevulinate synthetase, heme synthetase.

\section{INTRODUCTION}

The Baltic Sea is quite heavily polluted by a wide spectrum of contaminants. Tallinn lies on the southern coast of the Gulf of Finland. Previous investigations

*Corresponding author, muzyka@ekmi.ee 
of seawater, bottom sediments, algae, and fish tissues show that Tallinn urban bays, as well as bays outside the city area, including important fishing and recreation sites are contaminated with polycyclic aromatic hydrocarbons (PAH) (Veldre \& Bogovski, 1993). As a result of the intensive metabolism of contaminants in the fish organism, direct determination of these metabolites in the tissues need not reveal the real load of marine pollution. For the demonstration of the impact of this load various biomarkers are recommended.

The induction of the cytochrome P450 1A isoenzyme (CYP1A) in fish liver is generally regarded as a useful biomarker of exposure of fish to anthropogenic contaminants, such as PAHs, planar polychlorinated biphenyls (PCBs), and chlorinated dibenzo- $p$-dioxins and dibenzofurans (Collier et al., 1995). Associations between the activity of CYP1A, fluorescent aromatic compounds (FACs) in bile, and occurrence of hepatic lesions involved in the histogenesis of hepatic neoplasia have been demonstrated for flatfish species (Krahn et al., 1986; Myers et al., 1994; Collier et al., 1995). Flatfishes as bottom-dwelling species living in coastal regions that are repositories for wastes from anthropogenic sources often show accumulations of various chemical contaminants (Malins et al., 1987). Hepatic neoplasia and preneoplasia have been previously reported in flounder (Platichthys flesus L.) from different areas of the Baltic Sea (Bylund \& Wiklund, 1989; Wiklund \& Bylund, 1994; Bogovski, 1992, 1994; Lang \& Dethlefsen, 1994) The occurrence of hepatic neoplastic and preneoplastic lesions was higher in the north-eastern part of the Baltic Sea (Estonian and partly Latvian waters) than in the south-western Baltic Sea (Bogovski et al., 1999a).

Assay of the activity of aryl hydrocarbon hydroxylase (AHH), which depends on the CYP1A level in fish liver, has been recommended for monitoring programmes, because the data resulting from this method are more consistent and informative than those from the ethoxyresorufin $O$-deethylase (EROD) method, another catalytic assay (Collier et al., 1995).

Heme plays a central role in CYP synthesis and is required as a positive regulator of CYP gene expression (De Matteis, 1988). The system of heme synthesis consists of eight separate steps (Thunell, 2000). The first, rate-limiting step for the entire system, is synthesis of 5-aminolevulinic acid (ALA), which is catalysed by ALA synthetase (ALA-S). Heme synthetase (HEM-S) carries out the last step of heme synthesis, catalysing the incorporation of ferrous ion into the protoporphyrine molecule.

AHH activities, total CYP levels, and ALA-S and HEM-S activities were measured in our previous studies of flounder liver. The results indicated sufficient differences in these indices between urban and nonurban sites in the Tallinn area in 1994 (Bogovski et al., 1998) as well as differences among flounder from 6 sites along the Baltic Sea coastline from Germany to Estonia (Bogovski et al., 1999b).

During the last decade, the economic and environmental protection policies have changed drastically in Estonia (Estonian Environment, 1995): municipal sewage and waste treatment facilities have been reconstructed; most of the larger industrial plants polluting the air and water environments, such as a major pulp and paper mill in Tallinn, were closed; and the motor vehicles are now utilizing 
fuels of higher quality as compared with the early 1990s. Therefore, the objective of the current study was to investigate the changes in marine pollution in the Tallinn area from 1994 to 1999, comparing potential temporal changes of biomarkers investigated in European flounder.

\section{MATERIAL AND METHODS}

\section{Fish sampling}

Flounder larger than $25 \mathrm{~cm}$ in total length were collected from three areas of the Gulf of Finland (Fig. 1). Fish were collected from two urban sites of Tallinn Bay: from the Pirita area in 1996 and 1999 and from Kakumäe in 1994 and 1999.

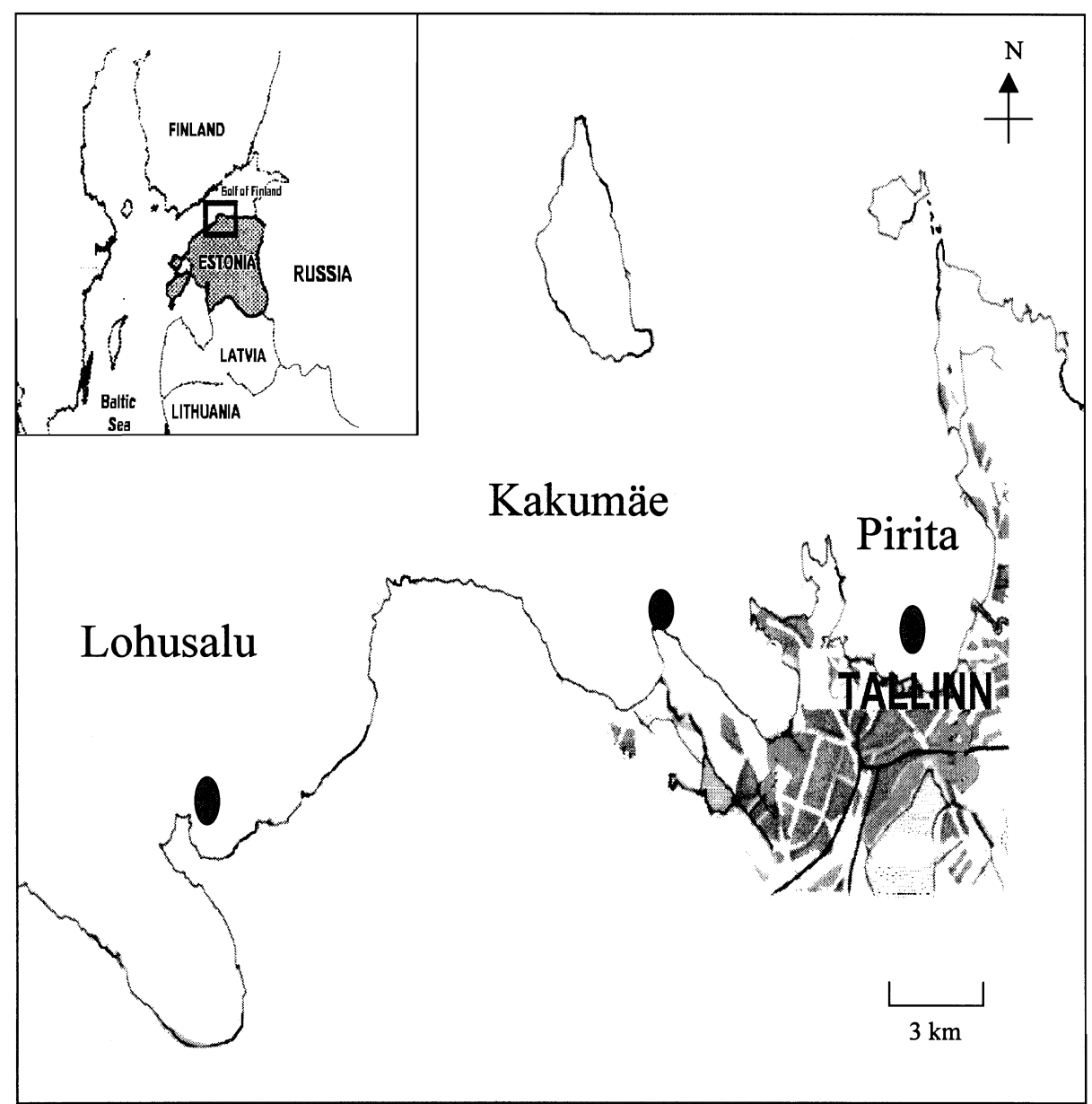

Fig. 1. Sampling sites in the Tallinn area of the Gulf of Finland (scale 1:300 000). 
From the nonurban reference area (40 km west of Tallinn, Lohusalu) fish were collected in 1994, 1996, and 1999. Fish were obtained from commercial gillnet catches, each year in the same season (July to August). They were placed on ice, delivered within 20-40 min to the laboratory, and necropsied.

\section{Biochemical analyses}

The microsomal fraction was obtained from fresh liver tissue according to Ahokas et al. (1975). Microsomal protein was measured by the method of Gornall et al. (1949). Levels of CYP were determined according to the method of Omura $\&$ Sato (1964). AHH activities were measured according to the method described by Holder et al. (1975). CYP levels and AHH activities were measured in 228 flounder (54 from Pirita, 52 from Kakumäe, and 122 from Lohusalu).

Aliquots of mitochondria suspension were used for the determination of ALA-S and HEM-S activities. The ALA-S activity was determined according to Bottomley \& Smithee (1968) in the modification of Muzyka (1972). The HEM-S activity was determined as described by Yoneyama et al. (1965). The ALA-S and HEM-S activity was measured in 153 flounder (40 from Pirita, 38 from Kakumäe, and 75 from Lohusalu).

\section{Analyses of aromatic compounds}

Analysis of FACs in bile as a biomarker of PAH exposure was carried out because it was regarded as a more precise method for measuring PAH exposure in fish than analysis of individual compounds in liver and muscle tissues, due to the extensive metabolism of PAHs in teleosts (Krahn et al., 1986). Bile was removed from the gall bladder of 121 flounder from Pirita $(1996,1999), 22$ flounder from Kakumäe (1999), and 89 flounder from Lohusalu (1996, 1999), and pooled samples were analysed for metabolites of aromatic compounds. A Specord M-40 (Carl Zeiss, Jena) spectrophotometer with a fluorescence detector was used for detection. Ethyl acetate extracts were measured at the typical benzo $(a)$ pyrene (BaP) excitation/emission wavelength pair, 380 and $430 \mathrm{~nm}$. Types of compounds

that fluoresce at this wavelength pair include: (1) $\mathrm{BaP}$ and metabolites; (2) other PAHs (e.g. pyrene, fluoranthene) and metabolites; and (3) possibly N-, S- or O-containing analogues (Krahn et al., 1986). In 1996 PAHs were measured in liver tissues and in stomach contents of 20 flounder from Lohusalu, 22 from Kakumäe, and 18 from Pirita according to the method described by Veldre \& Itra (1991).

\section{Statistical analyses}

Statistical analyses were performed using the SPSS 7 software program by one-way analysis of variance (ANOVA). Results are expressed as mean \pm SD. The site differences were considered significant at $p<0.05$, with independent analyses performed for all biomarker categories. 


\section{RESULTS}

The levels of FACs in bile of the flounder from Pirita, Kakumäe, and Lohusalu sites were equal and very low $\left(0.06 \pm 0.12 \mu \mathrm{g} \mathrm{kg}^{-1} \mathrm{BaP}\right.$ equivalents) in 1996 and 1999, with no apparent intersite differences. Bile FACs levels were not assessed at these sites in 1994, but the summarized levels of PAHs measured in fish liver tissues differed significantly in the urban and rural sites being $207 \pm 45$ and $42 \pm 25 \mu \mathrm{g} \mathrm{kg}^{-1}$, respectively (Bogovski et al., 1998). The levels of PAHs in liver tissues as well as in stomach contents of the flounder captured from Pirita and Lohusalu in 1996 measured using the same protocol were below the detection limit $\left(0.005 \mu \mathrm{g} \mathrm{kg}^{-1}\right)$.

Comparison of the levels of the biomarkers in the flounder from the nonurban site, Lohusalu, in 1994, 1996, and 1999 revealed some temporal differences (Table 1). The most drastic changes occurred in the AHH activity, which was significantly lower in 1996 and 1999 than in 1994. The total CYP level had also diminished significantly during the period from 1994 to 1996 and 1999. The activity of ALA-S decreased slightly between 1994 and 1999 at this reference site. The activity of HEM-S was slightly elevated in 1996 but increased significantly in 1999 . These changes generally corresponded to intrasite alterations in biliary FACs and PAHs levels in fish tissues over the same time period.

Table 1. Levels of cytochrome P450 (CYP) and aryl hydrocarbon hydroxylase (AHH), 5-aminolevulinic acid synthase (ALA-S), and heme synthase (HEM-S) activities in flounder liver from the Tallinn area of the Gulf of Finland

\begin{tabular}{|c|c|c|c|c|c|c|c|c|c|}
\hline \multirow{2}{*}{ Site } & \multirow{2}{*}{ Year } & \multicolumn{2}{|r|}{ CYP } & \multicolumn{2}{|r|}{$\mathrm{AHH}$} & \multicolumn{2}{|r|}{ ALA-S } & \multicolumn{2}{|c|}{ HEM-S } \\
\hline & & $n$ & Mean \pm SD & $n$ & Mean \pm SD & $n$ & Mean \pm SD & $n$ & Mean \pm SD \\
\hline \multirow{3}{*}{$\begin{array}{l}\text { Nonurban } \\
\text { (Lohusalu) }\end{array}$} & 1994 & 40 & $18.3 \pm 19.8$ & 40 & $424 \pm 752$ & 39 & $3.18 \pm 0.90$ & 39 & $0.30 \pm 0.13$ \\
\hline & 1996 & 67 & $\begin{array}{l}7.6 \pm 4.8 \\
p<0.05\end{array}$ & 67 & $\begin{array}{l}98 \pm 179 \\
p<0.05\end{array}$ & 32 & $\begin{array}{c}3.02 \pm 0.59 \\
p>0.05\end{array}$ & 32 & $\begin{array}{c}0.25 \pm 0.07 \\
p>0.05\end{array}$ \\
\hline & 1999 & 15 & $\begin{array}{l}4.3 \pm 2.3 \\
p<0.05\end{array}$ & 15 & $\begin{array}{c}64 \pm 52 \\
p<0.05\end{array}$ & 4 & $\begin{array}{c}2.48 \pm 0.66 \\
p>0.05\end{array}$ & 4 & $\begin{array}{c}0.41 \pm 0.08 \\
p<0.05\end{array}$ \\
\hline \multirow{2}{*}{$\begin{array}{l}\text { Urban } \\
\text { (Kakumäe) }\end{array}$} & 1994 & 40 & $35.0 \pm 25.6$ & 40 & $494 \pm 549$ & 34 & $7.56 \pm 1.26$ & 34 & $0.51 \pm 0.16$ \\
\hline & 1999 & 12 & $\begin{array}{l}8.3 \pm 4.9 \\
p<0.05\end{array}$ & 12 & $\begin{array}{c}86 \pm 61 \\
p<0.05\end{array}$ & 4 & $\begin{array}{c}3.40 \pm 0.25 \\
p<0.05\end{array}$ & 4 & $\begin{array}{c}0.47 \pm 0.09 \\
p>0.05\end{array}$ \\
\hline \multirow{2}{*}{$\begin{array}{l}\text { Urban } \\
\text { (Pirita) }\end{array}$} & 1996 & 40 & $90.1 \pm 43.9$ & 40 & $482 \pm 60$ & 36 & $5.22 \pm 0.95$ & 36 & $0.26 \pm 0.10$ \\
\hline & 1999 & 14 & $\begin{array}{l}5.8 \pm 3.5 \\
p<0.05\end{array}$ & 14 & $\begin{array}{c}73 \pm 63 \\
p<0.05\end{array}$ & 4 & $\begin{array}{c}5.93 \pm 0.29 \\
p>0.05\end{array}$ & 4 & $\begin{array}{c}0.47 \pm 0.03 \\
p<0.05\end{array}$ \\
\hline
\end{tabular}

AHH - pmol BaP metabolized $\mathrm{mg}^{-1}$ protein $\mathrm{min}^{-1}$; CYP - pmol CYP $\mathrm{mg}^{-1}$ protein; ALA-S $\mu$ mol ALA mg ${ }^{-1}$ protein $\mathrm{h}^{-1}$; HEM-S - nmol protoporphyrin $\mathrm{mg}^{-1}$ protein $\mathrm{h}^{-1}$. 
In Kakumäe, the first urban site investigated initially in 1994, the activities of AHH and ALA-S, as well as the total level of CYP in flounder liver were significantly lower in 1999 than in 1994. HEM-S activities did not show any significant changes during these years. The other urban area, Pirita, situated close to the city centre and ports, was investigated in 1996 and 1999. The AHH activities in the liver of the flounder from this site decreased slightly over the period, in contrast to the total CYP level, which decreased drastically. The activities of HEM-S increased significantly during the period investigated, while the activities of ALA-S remained unchanged.

\section{DISCUSSION}

Flounder from 6 sites along the Baltic Sea coastline from Germany to Estonia were investigated according to the same protocol as in the present study during the ICES/BMB sea-going workshop in 1994. The AHH activities in the liver of the flounder collected from an Estonian nonurban site were significantly lower than in the south-eastern sites and did not differ significantly from the western sites of the Baltic Sea. Moreover, FACs levels in bile were below the detection limit in the flounder from that Estonian site. In contrast, the total CYP level, as well as the ALA-S and HEM-S activities, were significantly higher in the flounder liver from the Estonian site compared to all other sites investigated (Bogovski et al., 1999b).

The intersite differences for the values of some biomarkers between the urban (Kakumäe) and nonurban (Lohusalu) sites in the Tallinn area of the Gulf of Finland were shown in our previous study carried out in 1994 (Bogovski et al., 1998). At that time, the total levels of CYP, aminopyrine $N$-demethylase, ALA-S, and HEM-S activities in the flounder liver from the urban site were higher than in the nonurban site; the AHH activity was only insignificantly elevated in the urban flounder. The levels of PAHs measured in tissues were higher in flounder from the urban site.

The results of the present study show that the AHH activities in the flounder liver microsomal fraction decreased between 1994 and 1999 at all sites investigated in the Tallinn area. However, these conclusions are limited because of the fact that these reductions are based on only two temporal data points in the case of the urban sites of Kakumäe and Pirita. Such decreases suggest a reduction of the exposure to PAHs in fish over these five years. This lowered hepatic AHH activity is at least circumstantially associated with our data showing low FACs levels in flounder bile in 1996 and 1999 at all sites investigated. The same tendency was evident in the data on total CYP levels over time. This may suggest that the load and effects of other contaminants have also diminished.

It is well known that a decrease in the HEM-S activity caused by exposure to toxic agents leads to enhancement of ALA synthesis (Thunell, 2000). Consistent with this relationship between toxicant exposure and HEM-S activity and ALA synthesis, the present study showed that ALA-S activities decreased and HEM-S 
activities increased in flounder liver mitochondria in all sites during the period of investigation.

These findings allow us to conclude that the contamination of the marine environments by toxic compounds such as PAHs appears to have fallen everywhere in the Tallinn area during the last three to five years. However, this conclusion will require confirmation by future sampling and analysis. Such positive changes may have ensued as a result of substantial changes in the Estonian economy and infrastructure, which in turn have improved the environmental situation.

The temporal changes of biochemical indices measured during this investigation correspond rather well. Besides changes in the AHH activity, which is a wellknown biomarker of carcinogenic pollution showing the induction of CYP1A isoenzyme as a response to the action of PAHs, PCBs, and dioxins, alterations were registered in the total levels of CYP and two heme synthesis enzymes ALA-S and HEM-S. This may reflect a wider spectrum of contaminants polluting the marine environments than expected. The present study demonstrates that AHH, CYP, ALA-S, and HEM-S investigated in flounder liver can serve as useful biomarkers of exposure to carcinogenic and other toxic compounds contaminating marine environments.

\section{REFERENCES}

Ahokas, J. T., Pelkonen, O. \& Kärki, N. T. 1975. Metabolism of polycyclic hydrocarbon hydroxylase in the liver of a trout species. Biochem. Biophys. Res. Comm., 63, 635-641.

Bogovski, S. 1992. Neoplastic changes in two Baltic fish species. Histopathological study. In Research in Medicine, p. 14. Tartu University, Tartu.

Bogovski, S. 1994. Neoplasia in flatfishes, particularly in flounders of the Baltic Sea. In Diseases and Parasites of Flounder in the Baltic Sea, The Baltic Marine Biologists Publication, No. 15 (Bylund, G. \& Lönnström, L.-G., eds.), pp. 99-104. Åbo.

Bogovski, S., Sergeyev, B., Muzyka, V. \& Karlova, S. 1998. Cytochrome P450 system and heme synthesis enzymes activity in flounder liver as biomarkers of marine environments pollution. Mar. Environ. Res., 46, 13-16.

Bogovski, S., Lang, T. \& Mellergaard, S. 1999a. Histopathological examinations of liver nodules in flounder (Platichthys flesus) from the Baltic Sea. ICES J. Mar. Sci., 56, 148-151.

Bogovski, S., Sergeyev, B., Muzyka, V. \& Karlova, S. 1999b. Correlations between cytochrome P450, haem synthesis enzymes, and aromatic compounds in flounder (Platichthys flesus) from the Baltic Sea. ICES J. Mar. Sci., 56, 152-156.

Bottomley, S. S. \& Smithee, O. A. 1968. Characterization and measurement of ALA-synthesis in bone marrow mitochondria. Biochim. Biophys. Acta, 159, 27-37.

Bylund, G. \& Wiklund, T. 1989. Liver conditions of flounder (Platichthys flesus) in the northern Baltic Sea. In Diseases of Fish and Shellfish. Abstracts from IV EAFP International Conference. Santiago de Compostella, Spain. Sept. 24-28, 1989, p. 184.

Collier, T. K., Anulacion, B. F., Stein, J. E., Goksøyr, A. \& Varanasi, U. 1995. A field evaluation of cytochrome P4501A as a biomarker of contaminant exposure in three species of flatfish. Environ. Toxicol. Chem., 14, 143-152.

De Matteis, F. 1988. Toxicological aspects of liver heme biosynthesis. Semin. Hematol., 25, 321-329.

Estonian Environment. 1995. Proceedings of the Ministry of the Environment of Estonia. Environmental Information Centre, Tallinn. 
Gornall, A. D., Bordavill, C. J. \& David, M. N. 1949. Determination of serum proteins by means of the biuret reaction. J. Biol. Chem., 177, 151-166.

Holder, G., Yagi, H., Levin, W., Lu, A. Y. H. \& Jerina, D. M. 1975. Metabolism of benzo(a)pyrene. III. An evaluation of the fluorescence assay. Biochem. Biophys. Res. Comm., 65, 13631370 .

Krahn, M. M., Rhodes, L. D., Myers, M. S., Moore, L. K. \& MacLeod, W. D. 1986. Associations between metabolites of aromatic compounds in bile and the occurrence of hepatic lesions in English sole (Parophrys vetulus) from Puget Sound, Washington. Arch. Environ. Contam. Toxicol., 15, 61-67.

Lang, T. \& Dethlefsen, V. 1994. Externally visible diseases and liver neoplasms in flounder (Platichthys flesus) of the south-western Baltic Sea. In Diseases and Parasites of Flounder in the Baltic Sea, The Baltic Marine Biologists Publication, No. 15 (Bylund, G. \& Lönnström, L.-G., eds.), pp. 39-47. Åbo.

Malins, D. C., McCain, B. B., Myers, M. S., Brown, D. W., Krahn, M. M., Roubal, W. T., Schieve, M. H., Landahl, J. T. \& Chan, S.-L. 1987. Field and laboratory studies of the etiology of liver neoplasms in marine fish from Puget Sound. Environ. Health Perspect., 71, $5-16$.

Muzyka, V. I. 1972. Determination of 5-aminolevulinic acid in erythrocytes. Lab. delo, 10, 603605 (in Russian).

Myers, M. S., Stehr, C. M., Olson, O. P., Johnson, L. L., McCain, B. B., Chan, S.-L. \& Varanasi, U. 1994. Relationships between toxicopathic hepatic lesions and exposure to chemical contaminants in English sole (Pleuronectes vetulus), starry flounder (Platichthys stellatus), and white croaker (Genyonemus lineatus) from selected marine sites on the Pacific coast, USA. Environ. Health Perspect., 102, 200-215.

Omura, T. \& Sato, R. 1964. The carbon monooxide-binding pigment of rat liver microsomes. J. Biol. Chem., 239, 2370-2378.

Thunell, S. 2000. Porphyrins, porphyrin metabolism and porphyries. I. Update. Scand. J. Clin. Lab. Invest., 60, 509-540.

Veldre, I. \& Bogovski, P. 1993. Polynuclear aromatic hydrocarbons in Estonian coastal waters. Proc. Estonian Acad. Sci. Ecol., 3, 149-157.

Veldre, I. \& Itra, A. 1991. PAH in the water medium of the Estonian SSR and their monitoring. In Polynuclear Aromatic Hydrocabons: Measurements, Means, and Metabolism. XIth International Symposium on Polynuclear Aromatic Hydrocarbons (Cooke, M., Loening, K. \& Merrit, J., eds.), pp. 939-948. Gaithersburg, Md., Battelle Press, Columbus.

Wiklund, T. \& Bylund, G. 1994. Diseases of flounder (Platichthys flesus (L.)) in Finnish coastal waters. In Diseases and Parasites of Flounder in the Baltic Sea, The Baltic Marine Biologists Publication, No.15 (Bylund, G. \& Lönnström, L.-G., eds.), pp. 49-52. Åbo.

Yoneyama, Y., Tamai, A., Yasuda, T. \& Yoshikawa, H. 1965. Iron-containing enzyme from rat liver. Biochim. Biophys. Acta, 105, 100-105.

\section{Muutused Läänemere lesta tsütokroom P450 süsteemis Tallinna piirkonna rannikuvetes aastail 1994-1999}

\section{Sergei Bogovski, Vladimir Muzõka, Boriss Sergejev ja Svetlana Karlova}

Merekeskkonna saastatuse uurimiseks aastail 1994-1999 määrati lesta maksas spektrofotomeetriliselt järgmisi biomarkereid: tsütokroom P450 (CYP) kogus; arüül-hüdrokarboon-hüdroksülaasi (AHH), 5-aminolevuliinhappe süntetaasi 
(ALA-S) ja heemsüntetaasi (HEM-S) aktiivsus. Lesta püüti Soome lahest Tallinna piirkonna püügipaikadest Piritalt, Kakumäelt ja Lohusalust. Viimasest saadud lestal osutusid AHH aktiivsus ja kogu CYP-i tase 1996. ja 1999. aastal usaldusväärselt madalamateks võrreldes 1994. aasta tasemega. ALA-S-i aktiivsus langes sellel ajavahemikul samuti. HEM-S-i aktiivsus tõusis 1999. aastal võrreldes 1996. aastaga. Kakumäel oli AHH ja ALA-S-i aktiivsus, nagu ka kogu CYP-i tase, lesta maksas 1994. aastal kõrgem võrreldes 1999. aastaga. Samal ajavahemikul ei ole märkimisväärseid muutusi HEM-S-i aktiivsuses täheldatud. Piritalt püütud lesta AHH aktiivsus nõrgenes mõnevõrra 1999. aastal võrreldes 1996. aastaga erinevalt kogu CYP-i tasemest, mis samal ajavahemikul langes järsult. HEM-S-i aktiivsus kasvas statistiliselt oluliselt, seejuures ALA-S-i aktiivsus jäi samaks.

Saadud tulemused näitavad, et vaadeldaval ajavahemikul on polütsüklilistest aromaatsetest süsivesinikest tingitud merekeskkonna saastatus langenud kõikjal Tallinna piirkonnas. Kuid samal ajal kinnitavad heemi sünteesi ensüümide kõrgenenud aktiivsus ja kogu CYP-i tase piirkonna jätkuvat saastatust. Seega oleks soovitav jätkata saasteainete ja nende toime seiret samas piirkonnas. 